\title{
Spinoza and Spinozism in the Western Enlightenment: the Latest Turns in the Controversy
}

\section{Spinoza y el Spinozismo en la Ilustración Occidental: los últimos giros de la controversia}

\author{
Jonathan Israel ${ }^{1}$ \\ Institute for Advanced Study, Princeton (Estados Unidos)
}

Recibido: 08-06-18

Aprobado: 31-07-18

\begin{abstract}
This article seeks to outline the main elements in the historiographical controversy over the significance of 'Spinozism' as an eighteenth-century Enlightenment category and the validity or otherwise of the concept of 'Radical Enlightenment' as well as the relationship between these two categories. Defining 'Radical Enlightenment' as the philosophical rejection of religious authority combined with a democratic tending system of social and political thought, and as a partly clandestine tradition that evolved in opposition to the moderate mainstream Enlightenment, it seeks to sketch in the main features both of the 'negative critique' broadly opposing this way of understanding the Western Enlightenment and the 'positive critique' that accepts this classification in broad outline.
\end{abstract}

Key-words: atheism, deism, 'Spinozism', 'sect of Spinozists', NeoSpinozists, cercle spinoziste, Neo-Epicureanism, Radical Enlightenment, Radikale Aufklärung, moderate Enlightenment, 'above reason', anti-Scripturalism, clandestinity, Postmodernism.

\footnotetext{
${ }^{1}$ (jisrael@ias.edu). Jonathan Israel taught in the history department at University College London from 1974 to 2000, from 1985 as 'Professor of Dutch History and Institutions'. Since 2001 until his retirement in 2016, he was Professor of Modern History at the Institute for Advanced Study, Princeton. His The Dutch Republic. Its Rise, Greatness and Fall, 1477-1806 appeared in 1995. His Enlightenment interpretation with its focus on the 'Radical Enlightenment' he developed in a series of volumes, beginning with his Radical Enlightenment. Philosophy and the Making of Modernity 1650-1750 (Oxford, 2001).
} 


\section{Resumen}

En el presente artículo se aspira a resumir los principales elementos de la controversia historiográfica acerca del significado de "Spinozismo" como categoría de la Ilustración del siglo XVIII y de la validez o no del concepto de "Ilustración Radical", así como la relación entre ambas categorías. Al definir la "Ilustración Radical" como el rechazo filosófico de la autoridad religiosa, en combinación con un sistema de pensamiento social y político que propende a la democracia, y como una tradición en parte clandestina desarrollada en oposición a la corriente principal de la Ilustración, más moderada, el texto pretende bosquejar en sus rasgos distintivos tanto la "crítica negativa", fuertemente opuesta a ese modo de entender la Ilustración Occidental, como la "crítica positiva", que la acepta ampliamente.

Palabras-clave: ateísmo, deísmo, "Spinozismo", "secta de los spinozistas", "neospinozistas", 'cercle spinoziste', neo-epicureísmo, Ilustración Radical, 'Radikale Aufklärung', Ilustración moderada, 'above reason', anti-escrituralismo.

As early as the 1670 s, and continually, right through the eighteenth century, one finds numerous references in the contemporary controversial literature, theological, philosophical and historical, in all the Western European countries, to 'Spinoza' as supposedly the foremost and most dangerous of the 'atheists' threatening Christianity, society and the moral order generally, and the 'sect of Spinozists' specifically as the veritable hard-core of the libertine underground challenging all the structures of authority then in place.

It is fairly clear that there were two main reasons for this remarkable historical phenomenon. One was Spinoza's Bible criticism. Hobbes and other thinkers venturing into the field of Bible criticism preceded Spinoza in challenging the sacred character of Scripture and denying that the Pentateuch was of Mosaic origin, developing a powerful and sophisticated 'anti-Scripturalism', "but no-one," as the point was made by Spinoza's contemporary, the Zurich scholar Johann Heinrich Heidegger (1633-98), among the most eminent Swiss theologians of the age and one of those keenest to unite all the Swiss Reformed churches behind a relatively undogmatic compromise creed, "struck the foundations of the entire Pentateuch more disgracefully than Spinoza," or did so with greater audacia [sed nemo Spinoza indignius fundamenta Pentateuchi totius concussit.]. ${ }^{2}$ Denying the possibility of miracles, contending that everything, without exception, including the origins of life and the principles

\footnotetext{
${ }^{2}$ Johann Heinrich Heidegger, Exercitationes Biblicae, Capelli, Simonis, Spinozae et aliorum sive aberrationibus, sive fraudibus oppositae (Zurich, 1700), 304, 369, 385.
} 
of morality, is governed exclusively by unalterable and mathematically precise natural laws without any divine intervention, or knowing providence, benevolent or otherwise, remained wholly illicit in mainstream society and no other thinker so clearly stated or was so regularly associated with this forbidden viewpoint as Spinoza.

The second reason why Spinoza alone occupies this remarkable and extraordinary position in early modern Western culture was that no other thinker was considered to have systematized 'atheism' so as to turn it into a working philosophy to the same extent or as effectively as Spinoza. If there were, and had long been, many, philosophical 'atheists' publicly condemned as such, stretching back, via Vanini, to Epicurus and Lucretius, "je crois qu'il [i.e. Spinoza] est le premier," writes Bayle in his Dictionnaire, "qui ait réduit en système l'athéisme, et qui en ait fait un corps de doctrine lié et tissu selon les manières des geomètres...", a pronouncement that itself became immensely influential through the rest of the Enlightenment. ${ }^{3}$ As the Cambridge don, Brampton Gurdon (d.1741), son of a Suffolk gentleman and member of Parliament, expressed this point (following Bayle), in 1723, "Spinoza is the only person among the modern Atheists, that has pretended to give us a regular scheme of Atheism, and therefore I cannot act unfairly in making him the representative of their party, and in proving the weakness and absurdities of the

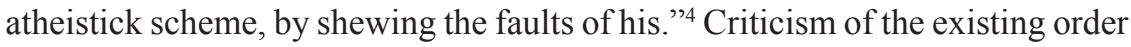
of things using 'atheistic' ideas as a tool to demolish accepted thinking long remained the exclusive speciality of a forbidden 'underground' philosophy associated with Spinoza's name rather than any other.

Although proclaiming Spinoza the chief and most prominent 'representative' of the underground atheistic tradition supposedly striving to undermine the main structures of authority underpinning Christendom has an astoundingly long history, from 1673 when we first encounter this notion that Spinozism was a forbidden philosophy being promoted, first in Holland, by an underground sect of disciples, ${ }^{5}$ called 'spinozistes', continuing down to the 1820 s, roughly lasting a century and a half, modern historians took very little interest in this striking phenomenon until the question became tied to the (since 2001) highly divisive issue of 'Radical Enlightenment'. The remarkable historiographical and philosophical controversy over the role of Spinoza and Spinozism in the Western Enlightenment generally sparked by the debate over 'Radical Enlightenment' since 2001, instead of receding after some years, as

\footnotetext{
${ }^{3}$ Françoise Charles-Daubert and Pierre-François Moreau (eds.), Pierre Bayle. Écrits sur Spinoza (Paris, 1983), p. 29.

${ }^{4}$ Brampton Gurdon, The Pretended Difficulties in Natural or Reveal'd religion No Excuse for Infidelity (London, 1723), p. 86.

5 Jonathan Israel, Radical Enlightenment. Philosophy and the Making of Modernity 1650-1750 (Oxford, 2001), p. 278.
}

Araucaria. Revista Iberoamericana de Filosofia, Política, Humanidades y Relaciones Internacionales, año 20, $\mathrm{n}^{\circ} 40$ Segundo semestre de 2018. Pp. 41-57. ISSN 1575-6823 e-ISSN 2340-2199 doi: 10.12795/araucaria.2018.i40.02 
one might expect from the normal course of historiographical controversies, has been escalating for more than a decade now especially since 2009 , in a dramatic fashion.

Recent developments in the discussion reveal the very wide scope and implications of this debate. No-one will dispute, I think, that the 'Radical Enlightenment controversy' entered a new and more mature stage during 2017 with the appearance of two valuable collections of essays, one edited by the Belgian scholar Steffen Ducheyne, in Brussels, the other edited in Paris and Madrid by the Spanish intellectual historian, Marta García-Alonso, each offering an overview of the whole controversy and providing a balanced impression of the range of conflicting views and the kinds of intellectual issues and questions at stake. These two overviews are Steffen Ducheyne (ed.) Reassessing the Radical Enlightenment (London, 2017) and Marta GarcíaAlonso, Les Lumières radicales et le politique (Paris, 2017).

But even before 2017 there had already been several earlier attempts to provide a broad perspective on this now highly complex 'Radical Enlightenment' controversy, notably the volume of essays Qu'est-ce que les Lumières "radicales". Libertinage, athéisme et spinozisme dans le tournant philosophique de l'âge classique (Paris, 2007), ${ }^{6}$ followed by the special issue of the Bordeaux journal Lumières (no. 22) entitled Lumières radicales et francmaçonnerie comprising seven contributions, published, in 2013, ${ }^{7}$ and, for the German public, the volume Radikalaufklärung, edited by Martin Muslow and myself, published by Suhrkamp, in Berlin, in 2014. However, before one can ponder the question of Spinoza's role and the meaning of the term 'Spinozists' in the Radical Enlightenment in any balanced fashion, one must first note the role attributed to Spinoza in the 'Radical Enlightenment thesis' itself with somewhat more precision than is usually the case. The sizeable body of critics who broadly reject the thesis put forward in my series of volumes commencing in 2001 with Radical Enlightenment, are often satisfied with simply stating that my thesis claims the Radical Enlightenment 'originated,' as some express it, in and essentially revolved around, the philosophy of Spinoza.

This way of expressing the point is trebly incorrect. ${ }^{8}$ In the first place, the term 'Radical Enlightenment', as I employ it, means combining rejection of religious authority with democratizing republican schemes for reforming society so that certain groups and individuals that were definitely, or possibly, not 'Spinozists' in any meaningful sense could nevertheless be part of the Radical Enlightenment. Among these non-Spinozist elements were radical

\footnotetext{
${ }^{6}$ Edited by Catherine Secrétan, Tristan Dagron and Laurent Bove.

${ }^{7}$ Lumières 22/ 2 (2013): 'Lumières radicales et franc-maçonnerie' (ed.) by Cécile Revauger and Jean Mondot.

${ }^{8}$ Jonathan Israel, 'Radical Enlightenment'- a Game-changing Concept,' in Steffen Ducheyne (ed.) Reassessing the Radical Enlightenment (London, 2017) pp. 15-47, here pp. 37-39.
}

Araucaria. Revista Iberoamericana de Filosofía, Política, Humanidades y Relaciones Internacionales, año 20, $\mathrm{n}^{\circ} 40$. Segundo semestre de 2018. Pp. 41-57. ISSN 1575-6823 e-ISSN 2340-2199 doi: 10.12795/araucaria.2018.i40.02 
Socinians and Unitarians like Jarig Jelles and Joseph Priestley who rejected all religious authority and mysteries they deemed incompatible with philosophicalscientific reason while at the same time espousing a democratic tendency. There were also certain 'deists', like Shaftesbury, who while meeting the criteria to be included under the rubric 'Radical Enlightenment' either expressly and genuinely repudiated Spinoza on moral or some other grounds or, like Mandeville, Franklin, Paine or Jefferson who thought of himself specifically as an 'Epicurean,' did not expressly, or altogether clearly reject the existence of a creator God separate from Nature.

In the second place, it goes against our argument to suggest that the 'Radical Enlightenment' 'originated' in the philosophy of any one particular thinker. Rather, Radical Enlightenment was an intellectual tradition, a group project, that began among a particular circle in a particular place, the cercle spinoziste, with important contributions to what evolved into 'Spinozism' as a historical category being made, in many cases before Spinoza himself published anything, by Franciscus van den Enden, Adriaen Koerbagh, Lodewijk Meyer, the Brothers De La Court, and several others. ${ }^{9}$ One of the few commentators to fully appreciate the significance of this qualification, PierreFrançois Moreau, noting that this circle, flourishing in Holland in the 1660s and 1670 s, was sometimes more republican, more democratic, more hostile to religion and more libertarian, than Spinoza himself, perceptively asked, not without an ironic touch: "was Spinoza then a 'Spinozist'? ${ }^{10}$ Moreau went on to throw doubt on whether Spinoza does evince a 'revolutionary impulse,' and to question whether the "Spinozist conception of the common good" promotes a political and social revolution based on the 'general will' and the cause of equality. This has been a topic of some dispute among Spinoza specialists in recent years and my viewpoint is probably not going to be readily accepted by some, or most others. Nevertheless, there are cogent grounds for arguing that Spinoza was a deliberate political as well as religious subversive and that what disappointed him about the English Revolution of the 1640s, for example, was not that King Charles lost his head, something that utterly horrified most Dutchmen at the time, but rather that the outcome was so paltry- essentially just Cromwell whom he dismisses as just another 'king' (that is tyrant), under another name.

But even if those critics who think that Spinoza disapproved of violent revolutionary upheavals as such, a point open to dispute, are right, that would not of itself negate the argument that his basic position entails fundamental opposition to kings and narrow oligarchies tied to rejecting religious authority.

\footnotetext{
${ }^{9}$ Israel, Radical Enlightenment, pp. 175-274.

${ }^{10}$ Pierre-François Moreau, 'Spinoza est-il spinoziste?" in Catherine Secrétan, Tristan Dagron and Laurent Bove (eds.) Qu'est-ce que les “Lumières radicales”?, pp. 289-97, here pp. 292-293
} 
While a broad, lasting opposition movement that exerts a major historical impact over a long period, like the Radical Enlightenment, must draw its vitality, impetus, durability and even ultimately its meaning from the social, economic and political context in which it flourishes, rather than from any thinker's or thinkers' ideas, ${ }^{11}$ it can, in one sense, 'originate' in the philosophy of a small group at a particular time if the initial intellectual articulation of the movement clearly commenced there. Radical Enlightenment was preceded by a long tradition of underground intellectual currents, including Neo-Epicreanism and Averroism, stretching back many centuries, and must have 'originated' in this broader sense in concrete historical realities, and a widespread social sense of grievance, as well as earlier debates; nevertheless, it is consistent with acknowledging this wider context, to maintain that the Radical Enlightenment's distinctive format, rejection of religious authority combined with democratizing republicanism, its arguments and intellectual orientation, commenced at a particular moment and in a particular place, in this instance a small group in Holland, the friends, allies and associates of Spinoza.

A third and final qualification to the notion of 'originated' needs to be noted. The Radical Enlightenment thesis as presented in my work does not claim that the late seventeenth and eighteenth century historical phenomenon contemporaries labeled 'Spinozism' or the 'sect of Spinozists' was necessarily steeped in, or closely tied, to Spinoza's own philosophy directly. It is by no means the intention to dispute the conclusion of the classic monograph of Paul Vernière, first published in 1954, that the leading French radicals of the High Enlightenment era - Diderot, d'Holbach, Helvétius, and Condorcet - mostly had only a fleeting, superficial knowledge of Spinoza's texts and rarely cite him directly, that Spinoza's philosophy as such ceased to be well-known or intensively studied after around 1730, before reviving again strongly, in Germany first, from the $1780 \mathrm{~s}^{12}$ What is meant by calling Diderot and his clan spinozistes, or neoSpinozists, is that unlike some other radicals, such as Shaftesbury or Priestley, they not only tied rejection of religious authority to a crypto-republican rejection of the social and political status quo, but comprehensively espoused philosophical necessitarianism, determinism, onesubstance doctrine, anti-Scripturalism, the principle that morality is purely a social tool invented by men that must reconcile individual self-interest with the common interest, and that priestly oppression inherently functions hand in hand with political tyranny.

While it is patently not the case that key figures such as d'Holbach and Condorcet delved deeply into Spinoza's thought, or cited him often or

\footnotetext{
${ }^{11}$ Israel, "Radical Enlightenment - a Game-changing Concept", pp. 36-40.

${ }_{12}$ Paul Vernière, Spinoza et la pensée française avant la Revolution (1954; $2^{\text {nd }}$ edn. 1982), pp. 699-700.
} 
in some cases ever, at the same time, one must acknowledge that the key elements constituting High Enlightenment French 'Spinozisme' in the sense intended here were not discovered or concocted by these post-1740 writers and thinkers but were transmitted to them by those sections of the pre-1730 radical philosophical underground literature, especially clandestine manuscripts and suppressed printed books, that were more directly immersed in Spinoza's own texts and thought. Those who performed this bridging role transmitting the basic elements of 'Spinozism' to the generation of Diderot and d'Holbach consisted of two distinct coteries. On the one hand there were those English 'deists', Toland, Tindal and Collins especially, who rejected Locke's dualism and principle of 'supra rationem' and adopted instead seemingly directly from, or else in emulation of, Spinoza, the latter's one-substance doctrine based on the idea that motion is inherent in matter, his necessitarianism, anti-Scripturalism and attack on 'priestcraft' along with his plea for full freedom of conscience and expression, or 'freedom to philosophize'. Secondly, there were a group of subversive Huguenot and other French thinkers in the years around 1700, and down to the 1730 s, whether or not they themselves can accurately be called 'Spinozists', who were deeply preoccupied with Spinoza's texts and bequeathed a powerful philosophical impetus to the generation of Diderot and d'Holbach. Especially important for the transmission of Spinozist ideas in France, and the literary depicting of an underground sect of 'Spinozists' pervading the whole of European culture, were Bayle, Boulainvilliers, and d'Argens but there were many others in this group, Tyssot de Patot among them.

Misunderstanding or misconstruing the argument, several proponents of the 'negative critique' as I shall henceforth refer to those scholars who oppose the basic narrative presented here (including Margaret Jacob), ${ }^{13}$ have seized one or other feature of this transmission process, supposing that it offers a reliable argument against the 'Spinozist' Radical Enlightenment thesis. The classic instance here is d'Holbach's indubitable and substantial debt to Toland. ${ }^{14}$ Margaret Jacob, for example, was right to point to the connection

13 The major critiques rejecting the Radical Enlightenment thesis as presented in my volumes are those of Antoine Lilti, Anthony La Vopa, Johnson Kent Wright, Keith Michael Baker, Harvey Chisick, Samuel Moyn, Dale Van Kley, Ursula Goldenbaum, Darryn McMahon, Annelien De Dijn, Jeremy Popkin, Paolo Casini, Ann Thomson, Carolina Armenteros, Theo Verbeeck, Dan Edelstein, Vincenzo Ferrone, Helena Rosenblatt, Joanne Stalnaker, Lynn Hunt, Margaret Jacob, David Bell, and Eduardo Tortarolo; among the foremost summaries presenting their arguments are: Antoine Lilti, "Comment écrit-on 1'histoire intellectuelle des Lumières? Spinozisme, radicalisme et philosophie" Annales. Histoire, Sciences Sociales (2009), 171-206; A.J. La Vopa, 'A New Intellectual History? Jonathan Israel's Enlightenment', Historical Journal 52 (2009), 717-38; and Harvey Chisick, "Interpreting the Enlightenment", The European Legacy, (2008), 35-57; for four particularly hostile interventions against the 'Radical Enlightenment' thesis's approach to the French Revolution, see H-France Forum, vol. 9 issue 1 (Winter 2014) no. 5; for a recent overview of the whole debate in Italian see Carlo Borghero, Interpretazioni, categorie, finzioni. Narrare la storia della filosofia (Florence, 2017), 31128, 505-507.

${ }^{14}$ Margaret Jacob, Radical Enlightenment. Pantheists, Freemasons and Republicans (revised $2^{\text {nd }}$ 
between Toland and d'Holbach but mistaken in thinking that this implies that 'Spinozism' was not at the root of d'Holbach's radicalism. For recent research into Toland, the work of Ian Leask in particular, has recently powerfully reinforced the proposition that Toland's rejection of Locke's dualism and 'supra rationem' and his Bible criticism and attack on priestcraft are much more firmly rooted in Spinoza and Spinozism than historians have been accustomed to think. As regards Toland, "one of the most significant Anglophone writers of the period," affirms Leask, "the extent of a general Spinozistic influence has been - if anything- under-determined and under-appreciated [even by Israel]." "15 While rejecting Locke's supra rationem and asserting one-substance materialism are Toland's key philosophical moves, concludes Leask, it is clear that "Toland remains committed throughout his writings, to the (thoroughly Spinozistic) dictum that the sole significance of Christianity is its universal, intelligible, moral precepts." 16

Broadly, the 'negative critique' rejects and opposes the thesis that the materialist, one-substance 'Radical Enlightenment' constituted a coherent tradition over generations or fundamentally divided the Enlightenment into clearly opposing tendencies, 'moderate' and 'radical'. ${ }^{17}$ Prima facie, the negative critique looks particularly weak in this regard, as it is obvious that it is totally impossible to sustain such a case on the basis of hard evidence. Despite this, many scholars steadfastly refuse to acknowledge any such rift as the essential key to understanding the inner dynamics and ultimate trajectory of the Enlightenment and the ensuing political revolutions of the 1775-1848 era, and this rejectionism gains added tenacity from the fact that their stance fits much better than does the approach I am offering both with the existing traditional historiography which makes no such fundamental distinction between moderate and Radical Enlightenment and also with Postmodernism which still lingers in favour with some.

A stock objection routinely presented by the 'negative critique' is the claim, insisted on first by Piet Stuurman, in 2002, that there is no necessary connection between democratic republicanism and rejection of religious authority, no inherent link between philosophical monism ruling out miracles, revelation and divine governance of history and revolutionary political ideas. ${ }^{18}$

edn., 2003), p. 20, p. 154, p. 286; Borghero, Interpretazioni, categorie, pp. 23-24, p. 113, p. 323.

${ }^{15}$ Ian Leask, 'Speaking for Spinoza? Notes on John Toland's Origines Judaicae' in Ducheyene, Reassessing, pp. 143-59, here p. 144; see also Ian Leask, 'The Undivulged Even in Toland's Christianity Not Mysterious' in W. Hudson, Diego Lucci and J.R.Wigelsworth (eds.) Atheism and Deism Revalued. Heterodox Religious Identities in Britain, 1650-1800 (Farnham, Surrey, 2014), pp. 63-80 and Ian Leask, 'Unholy Force: Toland's Leibnizian "Consummation" of Spinozism," in British Journal for the History of Philosophy 20 (2012), pp. 499-537.

16 Leask, 'Unidivulged Event', p. 79.

17 See Ducheyne, Reasssessing the Radical Enlightenment, and Marta García-Alonso, Les Lumières radicales et le politique. Études critiques sur les travaux de Jonathan Israel (Paris, 2017).

18 Piet Stuurman, 'Pathways to the Enlightenment', History Workshop Journal 54 (2002), pp.

Araucaria. Revista Iberoamericana de Filosofía, Política, Humanidades y Relaciones Internacionales, año 20, $\mathrm{n}^{\circ} 40$ Segundo semestre de 2018. Pp. 41-57. ISSN 1575-6823 e-ISSN 2340-2199 doi: 10.12795/araucaria.2018.i40.02 
This objection still appears weighty to many. But it is actually rather hard to see why. Asserting divine governance of the world and the need for priestly intercession to interpret and explain that 'governance', was undeniably the best available pillar for both royal power and aristocratic and ecclesiastical privilege. The facts again clearly show the incontestable role of religion in upholding hierarchical social systems and ecclesiastical privilege with the result that it is no coincidence that in the late eighteenth century most revolutionary democrats whether French, American, British or German were in fact atheists or non-providential deists. That both the pre-1789 texts denying religious authority and those denying social hierarchy relied on evasive techniques to get published, on a degree of clandestinity to develop, was an additional shared element - intellectual and social.

Clandestinity was a key integral feature of major sections of the French Enlightenment as in the rest of Europe but clearly had, or came to have, a dual function, masking both rejection of religious authority and, most notably during the 'war of the Encyclopédie', masking incipient republicanism and anti-aristocratism. ${ }^{19}$ Furthermore - and here Carl Schmitt becomes especially relevant - any anti-democratic principle of sovereignty emphatically not of the people or for the people, conceiving the essence of state as serving a higher order entirely superior to the people, cannot dispense with a religious or semisecularized 'political theology' to explain why the people's individual and collective interests should be subordinated to a supposedly higher and more authoritarian schema. Carl Schmitt saw Spinoza's greatest crime against authoritarian forms of government of the sort he advocated as his attempt, in contrast to Hobbes, decisively to expand the private sphere and individual liberty at the expense of state power. ${ }^{20}$ In this respect, there is indeed a Schmittian strand, or counter-strand, to our Radical Enlightenment thesis. All these considerations together sufficiently indicate that the main contentions of the 'negative critique', no matter how forcefully expressed- and sometimes the critics are rather virulent- simply miss the point.

Meanwhile, as the polemic has developed over the years, the "positive critique" countering the 'negative critique', has simultaneously evolved, with Giuseppe Ricuperati, Winfried Schröder, Sonja Lavaert, Matthew Stewart,

227-35; Harvey Chisick, 'Review Essay', in H-France Forum vol. 9 (issue 1, Winter 2014), pp. 5960; Karen Green, A History of Women's Political Thought in Europe, 1700-1800 (Cambridge, 2014), pp. 6-10.

${ }^{19}$ This entire topic of the clandestine philosophical literature is omitted from the recent Cambridge Companion to the French Enlightenment a work where Fontenelle and Fréret are not even mentioned in the index and that is comprehensively inadequate in almost every respect, see, Daniel Brewer (ed.) The Cambridge Companion to The French Enlightenment (Cambridge, 2014).

${ }^{20}$ Jeffrey Bernstein, "Nature's God" as Deus sive Natura: Spinoza, Jefferson, and the Historical Transmission of the Theological-Political Question', in Dustin Gish and Daniel Klinghard (eds.) Resistance to Tyrants, Obedience to God. Reason, Religion and Republicanism at the American Founding (Lanham, Maryland, 2013) pp. 77-78.

Araucaria. Revista Iberoamericana de Filosofia, Politica, Humanidades y Relaciones Internacionales, año 20, ${ }^{\circ} 40$. Segundo semestre de 2018. Pp. 41-57. ISSN 1575-6823 e-ISSN 2340-2199 doi: 10.12795/araucaria.2018.i40.02 
Charles Devellennes, María José Villaverde, Wayne Hudson, Maxime Rovere, Ian Leaske, Martha García-Alonso, Landon Frim, and Richard Wolin, among its chief proponents. ${ }^{21}$ The 'positive critique', contradicting the 'negative critique', broadly accepts the categories set out here envisaging the 'Radical Enlightenment' as a tendency closely linking rejection of religious authority with political and social revolutionary subversion tending toward democratic republicanism. The 'positive critique' broadly agrees that combining elimination of religious authority with democratizing republicanism produced a sweeping reform program aspiring to replace all prevailing principles of religion, morality, politics, social organization and education with a new general outlook rooted in materialist (or pantheist) monist philosophy. Such philosophy grounded an ideology that grew to become far more comprehensively revolutionary than the Enlightenment's public face, its moderate 'mainstream' rival, and shaped the universalist principles underlying the great declarations and legislation of the American and French revolutions. While asserting the Radical Enlightenment's reality as a clandestine underground that took root in various parts of Europe over a considerable span of time, Martin Mulsow's important divergent perspective differs from that presented here mainly, in denying the continuity and consistency of the Radical Enlightenment's philosophical ground-plan, playing down the democratic republican dimension, and the 'Spinozism' and focusing chiefly on the assault on Revelation and religious authority. It differs too in stressing the tradition's inconsistencies, unintended consequences, mystical elements, and group patterns.

The historiography of the Radical Enlightenment, the reader should also note (since the negative critique usually seems unaware of the precise background) reaches back well before the 1980s. The conservative German Jewish philosopher Leo Strauss (1899-1973) who first introduced the concept 'Radical Enlightenment' into scholarly discussion, in the $1920 \mathrm{~s},{ }^{22}$ viewed the Enlightenment-era phenomenon as deeply embedded in a far older, more variegated philosophical, social and cultural underground especially

\footnotetext{
${ }^{21}$ Notable contributions since 2009, include Philipp Blom, A Wicked Company: The Forgotten Radicalism of the European Enlightenment (2010); Matthew Stuart, Nature's God. The Heretical Origins of the American Republic (New York, 2014); Winfried Schröder, "Radical Enlightenment from a Philosophical Perspective' in Frank Grunert (ed.) Concepts of (Radical) Enlightenment. Jonathan Israel in Discussion in the Series: IZEA (Interdisziplinäre Zentrum für die Erforschung der Europäischen Aufklãrung, Halle), Kleine Schriften no. 5 (Halle, 2014) (2014), pp. 44-51; Sonja Lavaert, 'Radical Enlightenment, Enlightened Subversion, and Spinoza', Philosophica 89 (2014), pp. 49-102; and the essays in J.I. Israel and Martin Mulsow (eds.) Radikalaufklärung (Berlin 2014) especially those of Mulsow, Paganini, Silvia Berti, Wiep van Bunge, Antony McKenna, and Wilfried Schröder. Additional substantive contributors to the 'positive critique' are Wolin, Wayne Hudson, Charles Devellennes, Marta Garcia Alonso, Maria José Villaverde, Landon Frim, Nick Nesbitt, Ian Leask and Anthony DeSantis.

${ }^{22}$ On the origins of the term 'Radical Enlightenment' see Frederik Stjernfelt, "Radical Enlightenment": aspects of the history of a term', in Ducheyne (ed.) Reassessing, 80-103, here pp. 95-98.
} 
Epicureanism and late medieval Averroism and, differently from my own elaboration of the Radical Enlightenment since 2001, bracketed together the entire 'atheistic' tradition linking the Hellenistic world to modern times as constituting, or tending towards 'Radikale Aufklärung' [Radical Enlightenment], which in Strauss's view was indeed essentially 'atheism.' He saw it as a tendency that had existed in rudimentary form for centuries by the time we reach the early Enlightenment era. In my own approach, by contrast, the term 'Radical Enlightenment," is strictly reserved for the phenomenon combining rejection of religious authority with sweeping political and social reformism, observable first in the Netherlands from around 1660, and only afterwards in England and France. In Germany, as described by Martin Muslow, Radical Enlightenment viewed as a fresh impulse tying the attack on religion to elements of sweeping social reformism first became discernible, from around $1680 .{ }^{23}$

The thesis that the Enlightenment had two main strands, moderate and radical with only the latter being genuinely anti-religious and secular, first introduced in a developed, argued, fashion, by Strauss, in the 1920s,${ }^{24}$ entailed a philosophical bifurcation of the Enlightenment that was subsequently further developed by Strauss himself, Günter Mühlpfordt, ${ }^{25}$ Henry May, Giuseppe Ricuperati, Margaret Jacob (who, however, largely rejects the interpretation presented here), Silvia Berti, and Wim Klever. What he termed 'Radikale Aufklärung' [Radical Enlightenment], Strauss envisaged as preceding the 'Moderate Enlightenment' chronologically but also as outliving it. From the late seventeenth century onwards, 'Moderate Enlightenment' may have remained the principal reforming project in the eyes of governments, churches and educators and has remained so in the minds of most philosophers and historians ever since, but beneath the surface, in terms of effective arguments, held Strauss, the radical impulse proved sturdier philosophically and culturally, and in the long run showed itself to be the 'real' or principal Enlightenment, not least in shaping the Enlightenment's troubled legacy, the intellectual paradoxes and dilemmas of post-1800 modernity. ${ }^{26}$

\footnotetext{
${ }^{23}$ Miguel Benítez, Le Foyer clandestin des Lumières. Nouvelles recherches sur les manuscrits clandestins (2 vols., Paris, 2013) i, 13; Martin Mulsow, Enlightenment Underground. Radical Germany, 1680-1720 (Charlottesville, Virginia, 2015) , pp. 2-3, p. 16, p. 19, p. 24; Martin Mulsow, Prekäres Wissen. Eine andere Ideengeschichte der Frühen Neuzeit (Berlin, 2012) , p. 34, p. 45.

${ }^{24}$ Leo Strauss, Spinoza's Critique of Religion (1930; new English edn., Chicago, 1997), 35; Smith, Spinoza's Book of Life, 191; Nicolas Dubos rightly noted, in 2009, that when writing my earlier Enlightenment volumes I was still unaware that the radical-moderate dichotomy in Enlightenment historiography commences with Strauss in the 1920s, see Dubos, 'Hobbes et les Lumières radicales', in Secrétan, Dagron and Bove (eds.) Qu'est-ce que les "Lumières radicales"?, pp. 38-41.

${ }^{25}$ For republished articles of Mühlpfortdt's from the 1970s and 1980s, see, Günter Mühlpfordt, Halle- Leipziger Aufklärung. Kernstuck der Mitteldeutschen Aufklärung (Halle, 2011).

${ }^{26}$ On the Radical Enlightenment in America, see the books of Henry May, Matthew Stewart, Garry Nash, Seth Cotlar, Sean Wilentz and also my Expanding Blaze. How the American Revolution Ignited the World, 1775-1848 (Princeton, 2017).
} 
In fact, Strauss unhesitatingly classified Radikale Aufklärung as the veritable Enlightenment as well as essentially 'atheistic', while casting Locke, Voltaire, Montesquieu, Moses Mendelssohn and other apparently committed 'moderates' in the role of cautious compromisers who, with their unworkable philosophical 'fixes', unwittingly weakened rather than strengthened their ultimately highly precarious and untenable dualist philosophical edifices, their insistent but ultimately unsuccessful efforts at reconciling reason with religion, and philosophical critique with kings and courts. Strauss first employed the term Radikale Aufklärung as part of a general reinterpretation of the Enlightenment on which he embarked while researching Spinoza's Bible criticism in the mid- and late 1920s. ${ }^{27}$ Radikale Aufklärung to him was the Enlightenment's true core. But since, for Strauss, the label signified above all 'atheism', he chiefly identified what by 1928 he already termed 'Moderate Enlightenment' in terms of the latter's theistic premises and willingness to compromise with ecclesiastical authority. ${ }^{28}$

Eliminating religious authority, Strauss knew, must have far-reaching political and social consequences, but he hardly anywhere discusses this dimension in the early modern context. While not attaching any specific political character to the intellectual tendency, Strauss did maintain, highly significantly, that Radikale Aufklärung is above all characterized by its purely naturalistic conception of science, philosophy, and knowledge, a naturalism that radicals deployed, not unlike Nietzsche later, in his middle period, to ruthlessly strip out all supernaturalia. The Radikale Aufklärung conceived as an intellectual tradition, as Strauss describes it, insisted their standpoint was more objectively true, more demonstrably verifiable, than alternative philosophies, being more concretely open to verification by reason and scientific observation than either the views of Lockean moderates, like Voltaire, or traditionalist counterenlighteners, Christian or Jewish.

Rejecting my thesis since it has developed (from 1993), a great many scholars agree with the charge that the 'Spinozist' 'Radical Enlightenment thesis' as I have presented it, is misconstrued and based on 'shaky evidence.' Some would call this the prevailing opinion among Enlightenment experts. This is the 'negative critique' consensus. What is often applauded as the most effective and systematic critique for demonstrating this, that offered by Antoine Lilti, centers on challenging my use of the term 'Spinozism'. His very widely supported standpoint maintains that the use of the term spinozisme in eighteenth century France and western Europe generally is simply too elastic to sustain my broad conclusions in any meaningful way. Since Lilti's arguments have been

\footnotetext{
${ }^{27}$ See infra pp.

${ }^{28}$ Thomas Pangle, 'The Light shed on the Crucial Development of Strauss's Thought by his Correspondence with Gerhard Krüger', in M. D. Yaffe and R.S. Ruderman (eds.) Reorientation: Leo Strauss in the1930s (New York, 2014), pp. 59-63.
}

Araucaria. Revista Iberoamericana de Filosofía, Política, Humanidades y Relaciones Internacionales, año 20, $\mathrm{n}^{\circ} 40$ Segundo semestre de 2018. Pp. 41-57. ISSN 1575-6823 e-ISSN 2340-2199 doi: 10.12795/araucaria.2018.i40.02 
seconded by numerous scholars, it is important for readers to realize that there is a good deal of incoherence in this position which, indeed, when examined carefully seems altogether untenable. To agree with Lilti means arguing that even though writers all over Europe from around 1670 very frequently claimed that Spinoza and 'Spinozism' constituted the most audaciously formulated threat to religion and the existing moral order, and no other labels are used to refer to this universally menacing phenomenon to the same extent, contemporaries did not mean anything concrete by this, surely an intrinsically absurd position.

Lilti is a leading proponent of Postmodernist deconstruction, instability of meanings, signification slippage and deep ambiguity, who wholly embraced Daniel Roche's contention that in the eighteenth century Spinoza was interpreted in a bewildering variety of ways, rendering it impossible to see eighteenth-century 'Spinozism' as any kind of coherent tradition. Rather than a "theoretical corpus, Spinozism, contend Roche and Lilti, is just "un scandale, la figure extreme de l'héterotoxie," a term irredeemably problematic. ${ }^{29}$ This contention is Lilti's chief argument against the 'Radical Enlightenment' thesis, and an argument that fulfils a key function in the 'negative critique' more generally. But no matter how enamoured one may be with Postmodernist instability of meanings and signification slippage, absolutely nothing can make spinozisme as employed in Diderot's Promenade and the Encyclopédie, or in High Enlightenment literature, compatible with Revelation, divine providence, religious authority, theism, mysticism, fideism, eclecticism, moral relativism, Aristotelian substances, Platonic ideals, Prisca theologia (natural religion), Cartesian dualism, Lockean dualism based on supra rationem, double truth, fixity of species, Epicurean swerves, La Mettrie's materialism, or skepticism. 'Spinozists' a term already in very wide use, in Britain, Germany, France, and Italy, as well as Holland well before 1700, and 'spinozisme' as used in eighteenth-century France, can never mean, or ever be blended with, any of these trends. It may not always be a rigorous philosophical-theological category. But it frequently was and Lilti's and Roche's idea that 'spinozisme' meant lots of different things to different people is assuredly just a ridiculous sleight of hand, of no conceivable value for historical analysis.

To regard Voltaire's repeated, specific, clear usage of the term spinozisme as being so elastic as to have little real meaning would be as ill-advised and foolish as to make this point with respect to Diderot, Lessing, Goethe, or Herder, indeed every case that matters. If Spinoza's way of presenting his arguments, his 'geometric method', appeared "terribly archaic to Diderot" and the 'new Spinozists' of the 1750s, all these other figures, as Lilti himself concedes at one point, nevertheless intended 'to follow [Spinoza] in the 'consequences' of his

${ }^{29}$ Lilti, 'Comment écrit-on 1'histoire intellectuelle', 188-9, 192; Borghero, Interpetazioni, categorie, p. 506.

Araucaria. Revista Iberoamericana de Filosofia, Politica, Humanidades y Relaciones Internacionales, año 20, $\mathrm{n}^{\circ} 40$ Segundo semestre de 2018. Pp. 41-57. ISSN 1575-6823 e-ISSN 2340-2199 doi: 10.12795/araucaria.2018.i40.02 
system." It is true that no-one has been more congratulated for his efforts to demolish the 'Radical Enlightenment thesis' than Lilti. Antonio Negri, labeled, his critique a "remarkable analysis' that has indeed "demolished" that thesis. ${ }^{30}$ But this only proves once again the pervasive weakness of the "negative critique,' the extreme fragility of its critical effort which careful readers will encounter again and again.

Contrary to Roche, Lilti, and here also Borghero, it makes no difference whether, as with Diderot's specific usage in his Promenade, a writer has only skeletal, or profound, knowledge of Spinoza's texts, spinozisme wherever used during the Enlightenment cannot in any context ever meaningfully signify anything else but conflating body and soul into one, God and Nature into one, a universal morality based on the 'common good' and the laws of physics and rules of mathematics being conceived as one unified body of doctrine excluding divine providence and miracles whereby all reality, the entire universe, is governed by one single invariable set of unalterable laws of nature with no reserved area outside it. It always means the total extinction of theology in favour of philosophy and science; it always means Christianity is reduced to nothing more than universal moral precepts. ${ }^{31}$ Roche's, Lilti's and Borghero's point may be very widely echoed, but it is going to be exceedingly difficult for supporters to show that it amounts to anything more than the most perfect Postmodernist fog of confusion, as profoundly misleading in every way with regard to Bayle and Toland, as it has been shown to be, with regard to Spinoza. $^{32}$

The intensity and scale of the present-day controversy reflects not so much the validity of arguments on either side - it is no easy task to find a criticism of the 'negative critique' which, on careful examination, might be tenable - but rather its drastic implications and how much is at stake: the very fact so 'virulent' a contest has developed with accusations abounding of 'bias', 'unscholarly use of sources', propensity to 'idealism', 'essentialism', 'reductionism' and 'rigidity', as Vincenzo Ferrone commented, shows the essential points of dispute remain unsettled and that it will take time before final conclusions can be drawn. ${ }^{33}$

\footnotetext{
${ }^{30}$ Antonio, Negri, Spinoza for our Time. Politics and Postmodernity (New York, 2013) , 17; Borghero, Interpetazioni, categorie, pp. 505-506.

${ }^{31}$ Jonathan Israel,'L'Histoire intellectuelle des Lumières et de la Révolution: une incursion critique' in La Lettre Clandestine 19 (2011), pp. 211-215.

${ }^{32}$ Lilti, 'How Do We Write the Intellectual History ?' cue 55; Israel,'L'Histoire intellectuelle', pp. 209-210.

${ }^{33}$ Vincenzo Ferrone, The Enlightenment. Histrory of an Idea (2010; English version, Princeton, 2015), 162; Israel, 'Radical Enlightenment - a game-changing concept', p. 17.
} 


\section{References:}

Benítez, Miguel: Le Foyer clandestin des Lumières. Nouvelles recherches sur les manuscrits clandestins (2 vols., Paris, 2013) i, 13;

Bernstein, Jeffrey: "Nature's God as Deus sive Natura: Spinoza, Jefferson, and the Historical Transmission of the Theological-Political Question", in Gish, Dustin and Klinghard, Daniel (eds.): Resistance to Tyrants, Obedience to God. Reason, Religion and Republicanism at the American Founding (Lanham, Maryland, 2013).

Blom, Philipp: A Wicked Company: The Forgotten Radicalism of the European Enlightenment (2010).

Borghero, Carlo: Interpretazioni, categorie, finzioni. Narrare la storia della filosofia (Florence, 2017).

Brewer, Daniel (ed.): The Cambridge Companion to The French Enlightenment (Cambridge, 2014).

Charles-Daubert, Françoise and Moreau, Pierre-François (eds.): Pierre Bayle. Écrits sur Spinoza (Paris, 1983).

Chisick, Harvey: "Interpreting the Enlightenment," The European Legacy, (2008), 35-57.

Chisick, Harvey: "Review Essay", in H-France Forum vol. 9 (issue 1, Winter 2014).

Dubos: "Hobbes et les Lumières radicales", in Secrétan, Dagron and Bove (eds.) Qu'est-ce que les "Lumières radicales"?, 38-41.

Ferrone, Vincenzo: The Enlightenment. Histrory of an Idea (2010; English version, Princeton, 2015).

García-Alonso, Marta: Les Lumières radicales et le politique. Études critiques sur les travaux de Jonathan Israel (Paris, 2017).

Green, Karen: A History of Women's Political Thought in Europe, 1700-1800 (Cambridge, 2014).

Gurdon, Brampton: The Pretended Difficulties in Natural or Reveal'd religion No Excuse for Infidelity (London, 1723).

Heidegger, Johann Heinrich: Exercitationes Biblicae, Capelli, Simonis, Spinozae et aliorum sive aberrationibus, sive fraudibus oppositae (Zurich, 1700).

Israel, J.I. and Mulsow, Martin (eds.) Radikalaufklärung (Berlin 2014).

Israel, Jonathan: " 'Radical Enlightenment'- a Game-changing Concept,'” in Ducheyne, Steffen (ed.): Reassessing the Radical Enlightenment (London, 2017).

Israel, Jonathan: "L'Histoire intellectuelle des Lumières et de la Révolution: une incursion critique" in La Lettre Clandestine 19 (2011), 211-215. 
Israel, Jonathan: Expanding Blaze. How the American Revolution Ignited the World, 1775-1848 (Princeton, 2017).

Israel, Jonathan: Radical Enlightenment. Philosophy and the Making of Modernity 1650-1750 (Oxford, 2001).

Jacob, Margaret: Radical Enlightenment. Pantheists, Freemasons and Republicans (revised 2nd edn., 2003).

La Vopa, A.J.: “A New Intellectual History? Jonathan Israel's Enlightenment", Historical Journal 52 (2009), 717-38.

Lavaert, Sonja: "Radical Enlightenment, Enlightened Subversion, and Spinoza", Philosophica 89 (2014), 49-102.

Leask, Ian: "Speaking for Spinoza? Notes on John Toland's Origines Judaicae" in Ducheyene, Reassessing, 143-59.

Leask, Ian: "The Undivulged Even in Toland's Christianity Not Mysterious" in W. Hudson, Diego Lucci and J.R.Wigelsworth (eds.) Atheism and Deism Revalued. Heterodox Religious Identities in Britain, 1650-1800 (Farnham, Surrey, 2014), 63-80

Leask, Ian: "Unholy Force: Toland's Leibnizian 'Consummation' of Spinozism" in British Journal for the History of Philosophy 20 (2012), pp.499-537.

Lilti, Antoine: "Comment écrit-on l'histoire intellectuelle des Lumières? Spinozisme, radicalisme et philosophie," Annales. Histoire, Sciences Sociales (2009), 171-206.

Moreau, Pierre-François: "Spinoza est-il spinoziste?" in Secrétan, Catherine; Dagron, Tristan and Bove, Laurent (eds.): Qu'est-ce que les "Lumières radicales?".

Mühlpfordt, Günter: Halle- Leipziger Aufklärung. Kernstuck der Mitteldeutschen Aufklärung (Halle, 2011).

Mulsow, Martin: Enlightenment Underground. Radical Germany, 1680-1720 (Charlottesville, Virginia, 2015).

Mulsow, Martin: Prekäres Wissen. Eine andere Ideengeschichte der Frühen Neuzeit (Berlin, 2012).

Negri, Antonio: Spinoza for our Time. Politics and Postmodernity (New York, 2013), 17.

Pangle, Thomas: "The Light shed on the Crucial Development of Strauss's Thought by his Correspondence with Gerhard Krüger", in Yaffe, M. D. and Ruderman, R.S. (eds.): Reorientation: Leo Strauss in the1930s (New York, 2014).

Schröder, Winfried "Radical Enlightenment from a Philosophical Perspective" in Grunert, Frank (ed.): Concepts of (Radical) Enlightenment. Jonathan Israel in Discussion in the Series: IZEA (Interdisziplinäre Zentrum für die Erforschung der Europäischen Aufklãrung, Halle), Kleine Schriften no. 5 (Halle, 2014). 
Stjernfelt, Frederik: "Radical Enlightenment: aspects of the history of a term", in Ducheyne (ed.) Reassessing, 80-103.

Strauss, Leo: Spinoza's Critique of Religion (1930; new English edn., Chicago, 1997).

Stuart, Matthew: Nature's God. The Heretical Origins of the American Republic (New York, 2014);

Stuurman, Piet: "Pathways to the Enlightenment", History Workshop Journal 54 (2002), 227-35.

Vernière, Paul: Spinoza et la pensée française avant la Revolution (1954; 2nd edn. 1982). 
